\title{
SPECIFIC ASPECTS OF COOPERATION BETWEEN NATIONAL AND INTERNATIONAL LAW ENFORCEMENT AGENCIES
}

\author{
ОСОБЛИВОСТІ СПІВПРАЦІ МІЖ НАЦІОНАЛЬНИМИ \\ ТА МІЖНАРОДНИМИ ПРАВООХОРОННИМИ ОРГАНАМИ
}

\author{
Kachynska M.O., Ph.D, associate professor \\ police activity and public administration department \\ Kharkiv National University of Internal Affairs
}

The article deals with some aspects of cooperation between national and international law enforcement agencies. Attention was drawn to the importance of improving cooperation between national law enforcement agencies in general and relevant police training institutions in particular. The concepts and types of interaction are analyzed. Forms of exchange of experience in the law enforcement sphere and ways of application of positive methods of police training are considered.

The author classified the cooperation of law enforcement agencies of a particular state with international law enforcement organizations and law enforcement agencies of foreign countries into the following types: practical cooperation; educational (educational); research.

Practical interaction between law enforcement agencies is considered as cooperation in the investigation of crimes, including transnational, investigative actions, prosecution of perpetrators, extradition of offenders and more.

The educational or educational form of interaction between law enforcement agencies provides for the opportunity to exchange experience in the field of crime prevention and combating. This form of interaction provides an opportunity to exchange positive practices, methods of prevention, detection, disclosure, investigation of offenses and crimes, as well as bringing perpetrators to justice. This interaction is classified into advisory and training.

Some provisions of international and national normative legal acts regulating interaction of law enforcement agencies of Ukraine with law enforcement agencies of foreign countries are analyzed.

Key words: educational institutions with specific conditions of education, educational police institutions, cooperation, law enforcement, police, interaction, police training, training, quests.

У статті розглянуто окремі аспекти співпраці національних та міжнародних правоохоронних органів. Звернуто увагу на важливість вдосконалення співпраці між національними правоохоронними органами загалом та відповідними поліцейськими навчальними закладами зокрема. Проаналізовано поняття та види взаємодії. Розглянуто форми обміну досвідом у правоохоронній сфері та способи застосування позитивних методик підготовки поліцейських.

Автор здійснив класифікацію співпраці правоохоронних органів конкретної держави із міжнародними правоохоронними організаціями та правоохоронними органами зарубіжних країни: практична співпраця, навчальна (освітня) співпраця, науково-дослідна співпраця.

Практичну взаємодію між правоохоронними органами розглянуто як співпрацю під час розслідування злочинів, у тому числі транснаціональних, проведення слідчих дій, притягнення винних до відповідальності, екстрадиції правопорушників тощо.

Навчальна або освітня форма взаємодії між правоохоронними органами передбачає можливість обміну досвідом у сфері превенції та протидії злочинності. Саме означена форма взаємодії передбачає можливість обміну позитивними практиками, методиками попередження, виявлення, розкриття, розслідування правопорушень та злочинів, а також притягнення винних до відповідальності. Означена взаємодія класифікована як консультативна та навчальна.

Навчальна, або освітня, форма взаємодії між правоохоронними органами здійснюється у формі проведення тренінгів, семінарів, курсів, конференціях тощо, які можуть бути проведені очно, або дистанційно з використанням сучасних засобів зв'язку. Також можуть використовуватись онлайн портали, модулі тощо, що передбачать змогу самостійно вивчати матеріал працівником поліції у зручний для нього час.

Проаналізовано окремі положення міжнародних та національних нормативно-правових актів, що регламентують взаємодію правоохоронних органів України з правоохоронними органами зарубіжних країн.

Ключові слова: навчальні заклади із специфічними умовами навчання, освітні поліцейські заклади, співпраця, правоохоронні органи, поліція, взаємодія, підготовка поліцейських, тренінги, квести.

The development of Ukraine as a social, legal European country has given impetus to new reform processes in a number of state bodies, including law enforcement agencies in general and the police in particular. The first stated that the main task of the National Police is to provide police services in the following areas:

- ensuring public safety and order; protection of human rights and freedoms, as well as the interests of society and the state;

- combating crime;

- providing services, within the limits specified by law, to persons who, for personal, economic, social or emergency situations, require such assistance [1].

It is recognized that the person of his rights and freedoms is of the highest social value, and therefore, all state and nongovernmental structures are aimed at providing, satisfying and protecting human needs [2].

The above indicates the relevance of the study of cooperation between national and international law enforcement agencies. After all, effective training of law enforcement officers, using modern effective teaching methods of foreign countries, gaining practical skills of cadets and trainees will enable to prepare the future police officer, as a highly qualified specialist

Undoubtedly, the transformation in the country and the reform of the law enforcement system in general and the National Police in particular, occurring in Ukraine, require the strengthening of law and order, the proper protection and protection of human rights and freedoms [3].

According to the current legislation, the relations in the spheres of police activity with the relevant authorities of other states and international organizations are based on international treaties, as well as on the constituent acts and rules of international organizations of which Ukraine is a member. The legal regulation of the activities of the police and international law enforcement organizations, law enforcement agencies of other countries is regulated by a number of international treaties, namely:

- Convention on Mutual Assistance in Criminal Matters between the Member States of the European Union 2000;

- European Convention on Mutual Assistance in Criminal Matters 1959 
Convention on Legal Assistance and Legal Relations in Civil, Family and Criminal Matters 1993.

The interaction of law enforcement agencies of a particular state with international law enforcement organizations and law enforcement agencies of foreign countries should be divided into the following types:

- practical interaction;

- educational (educational);

- research.

Practical interaction between law enforcement agencies is to cooperate in the investigation of crimes, including transnational, investigation, prosecution, extradition of offenders and more. This interaction of law enforcement agencies is regulated by a number of international legal acts, a prominent place among them:

- European Convention on Extradition 1957 [4],

- Additional Protocol to the European Convention on Extradition 1957 [5],

- Additional Protocol to the European Convention on Extradition 1975 [6].

The educational or educational form of interaction between law enforcement agencies provides for the opportunity to exchange experience in the field of crime prevention and combating. This form of interaction provides an opportunity to exchange positive practices, methods of prevention, detection, disclosure, investigation of offenses and crimes, as well as bringing the perpetrators to justice. It is advisable to divide the educational or educational form of cooperation between law enforcement agencies into such subspecies:

- advisory, that is, police officers of one country who use effective ways to combat crime present their work and advise on the possibilities of their use by police units in other countries,

trainees, i.e. police officers receive information on certain positive experiences and practices of police activities on crime prevention and counteraction, and acquire opportunities for their continued use in their law enforcement activities.

The educational or educational form of law enforcement interaction is carried out in the form of trainings, seminars, courses, conferences, etc., which can be conducted in-person or remotely using modern means of communication. Online portals, modules, etc. may also be used to allow the police officer to study the material independently at a convenient time for him or her.

Scientific-research interaction of law enforcement agencies of Ukraine with international law enforcement organizations and law enforcement agencies of foreign countries provides for the possibility of participation of scientists, researchers, practitioners of police and other law enforcement agencies in joint projects, activities, etc. in order to study the causes and conditions of wrongdoing, analysis of ways and methods of their detection and disclosure, establishment of effective methods and methods of prevention of illegal activities, as well as exchange of experience in in this area.

Courses conducted by the International Law Enforcement Academy occupy a prominent place in law enforcement courses. They were initiated by the United States Government and aim to:

Assist in establishing and operating effective cooperation between law enforcement agencies of different countries;

- Train police officers of the management unit;

- Improve skills of personnel;

- Promote partnerships between law enforcement agencies in relevant professional fields, including combating drug trafficking;

- Provide quality training and technical assistance in formulating tactics and strategies for police crime prevention and counteraction;

Bring together international law enforcement agencies to combat crime and terrorism [7].

One of the main organizations of the European Union aimed at sharing the experience of law enforcement is the European Police College. It began operations in 2001. Each year, the European Police College sets up training events in the form of training, courses, workshops, conferences, exchange programs, dual law enforcement programs, and more. The aforementioned institution cooperates effectively with law enforcement educational institutions, including training institutions for future police officers, EU countries, Norway and Ireland.

The main tasks of the European Police College are: enhancing the knowledge of police in the field of European justice. For example, regarding the functions and powers of Europol;

training officers in candidate countries wishing to join the European Union;

- training European Union police officers in joint activities, taking into account European customs legislation; deepening the knowledge of police officers about the police structures and systems of the Member States of the European Union [8].

The most effective event for the European Police College is the exchange program. It was created in accordance with the Hague Program (2004), the Stockholm Program, which was adopted by the partner countries of the College in 2009. The Erasmus-style program was used as the basis for the creation of the exchange program for police officers.

The European Police College's exchange program is intended to promote European law enforcement cooperation through training for the benefit of European citizens for the following purposes:

- Promote mobility and exchange of law enforcement personnel within practice-related training programs;

Establish common and common practical knowledge in different areas of law enforcement;

Disseminate and share good practice at European Union level;

- Promote the creation of a European law enforcement culture;

- Encourage mutual learning and networking within European law enforcement cooperation.

The exchange program is a flagship of the European Police College, launched in 2007. Following the positive results of this exchange program in 2010 , it switched to the financial section of the College's own budgetary allocations, which facilitated a more smooth and efficient management of the program.

Numerous changes have been made over the years to better adapt the needs of European law enforcement agencies in training staff to the problems they face. In 2016, the target group of the exchange program was extended to all law enforcement agencies. Under the new provision, not only police but also customs and tax authorities, border guards and prosecutors can benefit from this training tool.

The sharing of police experience that underlies the European Police College exchange program is the Erasmus style. The latter implies that training activities provide an opportunity to create a network of colleagues-police officers and an opportunity to become familiar with the methods of police work in other countries through the exchange of experience and knowledge sharing. In the long term, it contributes to building confidence and establishing more effective cooperation not only between EU Member States but also with all other countries involved, whose aspirations are in line with the aspirations of the European Security Program.

The program identifies priorities for combating and preventing terrorism, organized crime and cybercrime as interlinked areas with a strong cross-border dimension and aims to strengthen the tools that the EU provides to national law enforcement agencies to combat terrorism and cross-border crime. In particular, the European Police College exchange program aims at improving information sharing and improving operational cooperation between law enforcement agencies [8].

Therefore, the interaction of police academies and other law enforcement institutions in different countries allows one to study the experience of crime prevention and counteraction, as well as to establish and use positive methods of training law enforcement officers and successfully implement them in the activities of the respective educational institutions. 


\title{
REFERENCES
}

1. Про Національну поліцію України : Закон України від 02.07.2015 р. № 2612-VIII. URL: http://zakon.rada.gov.ua/laws/show/580-19

2. Конституція України : Закон України № 254к/96-BP від 28.06.1996р. URL: http://zakon.rada.gov.ua/laws/show/254к/96-вp

3. Управління органами Національної поліції України : підручник / за заг. ред. д-ра юрид. наук, доц. В.В. Сокуренка [О.М. Бандурка, О.І. Безпалова, О.В. Джафарова та ін.; передм. В.В. Сокуренка] ; МВС України, Харків. нац.ун-т внутр. справ. Харків : Стильна типографія, 2017. 580 c.

4. Європейська конвенція про видачу правопорушників : міжнародний договір від 13.12.1957 p. URL: http://zakon.rada.gov.ua/laws/ show/995 033

5. Додатковий протокол до Європейської конвенції про видачу правопорушників : від 15 жовтня 1957 p. URL: http://zakon.rada.gov.ua/ laws/show/995_034

6. Другий додатковий протокол до Європейської конвенції про видачу правопорушників : від 17 березня 1978 p. URL: http://zakon.rada.gov.ua/laws/show/995_035

7. International Law Enforcement Academies (ILEA) : станом на 29.11.2018 p. URL: http https://www.state.gov/j/inl/c/crime/ilea/

8. CEPOL European Union Agency for Law Enforcement Training : станом на 29.11.2018 p. URL: https://www.cepol.europa.eu/

УДК 342.9.796

DOIhttps://doi.org/10.32782/2524-0374/2019-4/32

\section{ПЛАНУВАННЯ ЗАБЕЗПЕЧЕННЯ ФІЗИЧНОЇ ПІДГОТОВКИ У ПРАВООХОРОННИХ ОРГАНАХ: ПИТАННЯ СЬОГОДЕННЯ}

\author{
PLANNING FOR PROVISION OF PHYSICAL TRAINING \\ IN LAW-ENFORCEMENT BODIES: THE QUESTION OF THE PRESENTATION
}

\author{
Ковальов І.М., к.ю.н., старший викладач \\ кафедри тактичної та спеціальної фізичної підготовки \\ Харківський національний університет внутрішніх справ \\ Артем'єв В.О., к.пс.н., доцент, \\ директор \\ Комплексна дитячо-юнацька спортивна школи № 8 \\ Харківської міської ради
}

\begin{abstract}
У статті фрізична підготовка у правоохоронних органах розглядається як внутрішньоорганізаційна адміністративна діяльність правоохоронних органів, реалізація якої здійснюється в рамках адміністративно-правових відносин, нормативно-правове забезпечення якої здійснюється в рамках адміністративного законодавства. Обґрунтовується, що планування фізичної підготовки у правоохоронних органах, як складова частина адміністративної діяльності, здійснюється на основі результатів комплексного аналізу стану і тенденцій розвитку фізичної підготовки, характеру вирішення навчальних і службово-бойових завдань під час проходження служби, наукового забезпечення у сфері фізичної культури і спорту тощо. Запровадження механізмів планування забезпечення фізичної підготовки для всієї системи правоохоронних органів, уніфікація та унормування процедури міжвідомчого планування дадуть змогу синхронізувати та гармонізувати розвиток фізичної підготовки, узгодити розподіл функцій і завдань суб'єктів цього напряму діяльності, організувати ефрективну взаємодію між ними та оптимізувати видатки державного бюджету.

Привертає увагу той фракт, що планування фізичної підготовки у правоохоронних органах становить собою процес вироблення управлінського рішення, що включає в себе сукупність рішень і складається з послідовних дій: по-перше, збір, систематизація та аналіз вихідної інформації, у тому числі пропозиції, що надходять від структурних підрозділів; підготовка проекту наказу; узгодження проекту наказу з відповідальними виконавцями і співвиконавцями; затвердження плану керівником; доведення плану до виконавців і співвиконавців. Доведено, що документи з планування фізичної підготовки у правоохоронних органах розробляються на довгостроковий, середньостроковий та короткостроковий періоди з метою посилення фізичної підготовки особового складу.

Ключові слова: фізична культура, фізична підготовка, правоохоронні органи, адміністративна діяльність правоохоронних органів,
\end{abstract} планування

The article states that the introduction of mechanisms for planning physical training for the entire system of law enforcement, unifying and standardizing the interagency planning procedure, will allow to synchronize and harmonize the development of physical training, to coordinate the distribution of functions and tasks of subjects in this area of activity, to organize effective interaction between them and to optimize the expenditures of the state budget. It is substantiated that planning of physical training in law enforcement bodies as a component of administrative activity is carried out on the basis of the results of a comprehensive analysis of the state and trends of the development of physical training, the nature of the solution of educational and service-combat tasks during the service, scientific support in the field of physical culture and sports, etc. Attention is drawn to the fact that the planning of physical training in law enforcement bodies is a process of developing a management solution that includes a set of decisions and consists of successively changing the action of one another, namely: first, collection, systematization and analysis of the source information, including proposals received from structural subdivisions; drafting a draft order; coordination of the draft order with responsible executors and co-executors; approval of the plan by the manager; bringing the plan to performers and collaborators. Consequently, planning documents for physical training in law enforcement agencies are developed for long-term, medium-term and short-term periods in order to enhance the physical training of personnel.

Key words: physical culture, physical training, law enforcement bodies, administrative activity of law enforcement bodies, planning.

Одним із найважливіших аспектів, який надає системності й цілеспрямованості процесу організації та здійснення фізичної підготовки у правоохоронних органах, $\epsilon$ планування. Планування - це складний методично-орга- нізаційний процес, за якого відбуваються безперервний пошук, оброблення й систематизація інформації та iii перетворення на знання про зовнішнє середовище та власні можливості правоохоронного органу в контексті 